\title{
Making It Count: Sexual Offences, Evidential Sufficiency, and the Mentally Disordered Complainant
}

\author{
Candida Saunders
}

Published online: 3 November 2010

(C) The Author(s) 2010. This article is published with open access at Springerlink.com

\begin{abstract}
Sexual offences are notoriously difficult to prove, even without the added evidential difficulties posed by a key prosecution witness with mental health problems. Yet, according to the annually published criminal justice statistics, the conviction rate for sexual activity with a person with a mental disorder is, on average, around three times greater than that for rape. This article begins by scrutinising the plausibility of such a counter-intuitive proposition, concluding that the greater success implied by the statistics is likely to be more apparent than real. In the process of reaching this conclusion, challenging questions surrounding the prosecution of sex cases involving mentally disordered complainants are raised. These substantive and practical issues are explored in a critical analysis of new empirical data and reported cases.
\end{abstract}

Keywords Prosecution - Charge selection - Sexual offences ·

Mental disorder impeding choice · Capacity

\section{Introduction: Perplexing Statistics}

During 2007-2009, the author conducted a qualitative socio-legal analysis exploring the factors influencing prosecutorial decision-making in a small sample $(n=17)$ of male rape cases. The study combined retrospective analyses of prosecution casefiles and in-depth interviews with the Crown Prosecutors responsible for decisionmaking in these cases. During the case-file analyses, basic data regarding particular characteristics and attributes of complainants and defendants were recorded, including age, sexuality, and any previous criminal convictions. A further routinelyrecorded attribute was 'disability', and its prevalence within the sample was both

C. Saunders $(\square)$

University of Nottingham, Nottingham, UK

e-mail: candida.saunders@nottingham.ac.uk 
striking and unanticipated: 'disability' was noted in 10 of the 17 sample cases. In six of these 'disability' cases, at least one complainant was known to have a mental disorder as defined in section 1 of the Mental Health Act (MHA) $1983^{1}$ which was-or, in the case of historic allegations, appeared to have been-operative at the time of the alleged offence.

The outcomes in these six cases involving mentally disordered complainants were as follows: police were advised by the Crown Prosecutor to take no further action in one case, resulting in the accused being released without charge; in five cases, the decision was taken to prosecute-defendants were charged with rape and the cases were sent for trial. One case, however, was subsequently terminated when the Crown offered no evidence on the day of trial. The four remaining cases were all prosecuted and resulted in convictions: two by means of defendants pleading guilty; and two by juries returning guilty verdicts after full contested trials.

This was a qualitative 'small $n$ ' study and was not a random sample. Neither the prevalence of mental disorder within the sample nor its apparently positive relationship with prosecution and conviction should therefore be regarded as representative of cases generally. While it is well documented that persons with mental health issues are at increased risk of experiencing criminal victimisation, both generally ${ }^{2}$ and in relation to sexual offences, ${ }^{3}$ the proportion of mentally disordered complainants in the male rape study (35\%) was considerably higher than that identified elsewhere. ${ }^{4}$ Similarly, although two-thirds of mentally disordered complainants in the male rape sample saw their defendants brought to justice, research elsewhere reports that cases involving such complainants are rarely prosecuted. ${ }^{5}$ This is not unique to sexual offences. Indeed, prosecutors may be reluctant to pursue a prosecution in any criminal case where a significant witness has mental health problems. ${ }^{6}$ Nevertheless, although clearly anomalous, the male rape data should not be dismissed out of hand. Mental disorder is notably prevalent among samples of sexually victimised populations. Moreover, annually published criminal justice statistics also suggest surprisingly high conviction rates for sexual offences perpetrated against persons with a mental disorder. Relevant data are set out in Table 1 below.

Given that the conviction rate for rape currently stands at around $6 \%$, these data are counter-intuitive. Unless we are prepared to accept that mentally disordered persons are perceived by fact-finders to be more reliable and more credible witnesses than the unimpaired complainant in most sex cases, then there must be some other factor or factors which explain the apparently greater success in bringing their offenders to justice. This article begins to explore what those factors might be.

\footnotetext{
1 Section 1(2) of the Mental Health Act 1983 provides that “"mental disorder" means any disorder or disability of the mind'.

2 For a comprehensive review, see McCracken et al. (2009).

${ }^{3}$ Home Office (2000a); Keenan and Maitland (2000); Home Office (2002).

${ }^{4}$ For example, a recent study identified $19 \%$ of complainants as having mental health problems: Horvath and Kelly (2009).

5 Kelly et al. $(2005,31)$.

${ }^{6}$ McCracken et al. (2009, 44); Lee and Charles (2008).
} 
Table 1 Sexual activity etc. with a person with a mental disorder

\begin{tabular}{lllll}
\hline Crime year & \# Recorded & Sentencing year & \# Convictions & Conviction rate \\
\hline- & - & 2004 & 1 & - \\
$2004 / 2005$ & 103 & 2005 & $22(18$ convictions/4 cautions $)$ & $21 \%$ \\
$2005 / 2006$ & 139 & 2006 & $24(15$ convictions/9 cautions $)$ & $17 \%$ \\
$2006 / 2007$ & 163 & 2007 & $29(20$ convictions/9 cautions $)$ & $18 \%$ \\
$2007 / 2008$ & 128 & 2008 & $23(19$ convictions/4 cautions $)$ & $18 \%$ \\
\hline
\end{tabular}

Data collated from Criminal Statistics and Sentencing Statistics for the relevant years. Pre-2006 reports are available on the Home Office website. Since 2006, these reports are published annually by the Ministry of Justice

Owing to its obvious methodological constraints, the analysis presented here is necessarily tentative and exploratory. Relevant data are confined to two sources, both of which are inherently limited in scope. The first source is the male rape study itself, containing six cases of allegations of non-consensual penetrative sex made by complainants with mental disorders. The second source is the law reports which, by September 2010, reported eleven cases involving appeals following convictions for sexual activity with a person with a mental disorder.

The scope of the analysis is further limited by the fact that all but two of the cases analysed here resulted in convictions. Given the sources of the cases, this is unsurprising ${ }^{7}$; given the absence of alternative or additional sources of information, this is also unavoidable. In addition, while all of the sample cases from the male rape study involve allegations of penetrative activity falling within the legal definition of rape set out in section 1 of the Sexual Offences Act 2003, the relevant cases in the law reports involve conduct ranging from penile penetrative activity to sexual touching. Criticisms of failing to compare like with like would, however, be misplaced in an exploratory analysis such as this; the broad area of interest here is mentally disordered complainants and the prosecution of sexual offences perpetrated against them. Analysed systematically, and with appropriate circumspection, these admittedly limited data may nonetheless provide us with some useful insights as to how and when the protection of the criminal law is extended to mentally disordered complainants in sex cases.

\section{Scrutinising the Numbers}

The counter-intuitive conviction rates presented in Table 1 demand closer scrutiny. The first step, however, is contextualisation. In 1999, the Sexual Offences Review

\footnotetext{
7 The cases from the law reports analysed here all involve appeals following conviction. The overrepresentation of convictions in the male rape study will, in large part, be explained by having identified cases via the CPS rather than police. Having been referred to prosecutors for charging advice, sample cases had already successfully passed through key attritional points in the criminal justice process. See further: Gregory and Lees (1996); Kelly et al. (2005); Feist et al. (2007).
} 
(SOR) was tasked by the Home Office with reviewing the common and statute law of England and Wales relating to sexual offences with the purpose of making recommendations for legislative reform. In its report, ${ }^{8}$ the SOR concluded that mentally disordered persons are particularly vulnerable to sexual victimisation, very little of which ever comes to the attention of the criminal justice system and even less of which results in prosecution or conviction. The SOR stated:

There were 6 prosecutions and 1 conviction for the specific offences of sex with a 'defective' in 1998. These statistics do not reveal the genuine extent of the problem. Abuse against vulnerable people may not come to light, and if it does, is unlikely to be reported to the police. There are considerable difficulties in both investigation and prosecution, and because of evidential difficulties cases may not proceed to court. Research has indicated that the incidence of sexual abuse of people with disabilities may be as much as four times higher than within the non-disabled population. ... Whatever the scope of abuse, it is clear it is extensive, and that the law does not provide a good remedy at present. ${ }^{9}$

Lamenting the systemic failure of the criminal justice process to call offenders to account, Mencap made the following poignant submission to the SOR:

In terms of sexual offences, and to oversimplify, those who can't communicate can't tell, and those who can't communicate well won't be believed. ${ }^{10}$

The SOR stated that it was 'profoundly moved by the extent of sexual abuse against vulnerable people ${ }^{, 11}$ and advanced a number of recommendations for legislative reform dealing specifically with sexual offences perpetrated against mentally disordered persons. ${ }^{12}$ Accepting the overall objectives of the SOR and adopting most of its recommendations, ${ }^{13}$ the Sexual Offences Act (SOA) 2003 came into effect in May 2004.

The 2003 Act criminalises sexual activity in three basic scenarios: (1) where there is no consent ${ }^{14}$; (2) where there can be no consent ${ }^{15}$; and (3) where, due to inducement ${ }^{16}$ or the relationship between the parties, ${ }^{17}$ sexual activity is prohibited

\footnotetext{
8 Home Office (2000a).

9 ibid: 4.2 .5 (footnotes omitted).

${ }^{10}$ Mencap submission to SOR, March 1999. Quoted in Home Office (2000a, 4.3.8).

11 ibid: 0.17 .

12 ibid: Chapter 4.

13 Home Office (2002).

14 The non-consent offences contained in SOA 2003, sections 1-4.

15 For example, the offences against persons with a mental disorder impeding choice in sections 30-33 SOA 2003; sexual offences perpetrated against those under 13 years of age (sections 5-8 SOA 2003); and, those under 16 years of age (sections 9-12 SOA 2003).

16 For example, procuring or engaging in sexual acts with or in the presence of a person with a mental disorder by inducement, threat or deception: Sections 34-37.

17 For example, abuse of position of trust offences in sections 16-19; familial child offences in sections 25-26; sexual activity between mentally disordered persons and their carers in sections 38-41; and familial adult offences in sections 64-65.
} 
regardless of consent. These different offence categories are neither discrete nor mutually exclusive; the same incident may simultaneously fall under more than one provision of the SOA 2003. For example, where penile penetration has occurred with a mentally disordered complainant, a rape charge under section 1 may be pursued on the basis that the complainant did not consent, or on the basis that she or he lacked the freedom and capacity to consent under section 74. Alternatively, if the complainant's mental disorder renders her or him unable to refuse, a charge of sexual activity with a person with a mental disorder impeding choice may be pursued under section 30 . If the defendant procured penetrative sexual activity with the mentally disordered complainant by inducement, threat or deception, then charges under section 34 may be preferred. ${ }^{18}$ Or, if the defendant was the complainant's carer, he may be charged with an offence under section $38 .{ }^{19}$ Finally, if the mentally disordered complainant was under the age of either 16 or 13 years, then the under-age sexual offences contrary to sections 9 or 5, respectively, may be pursued. With every offence except rape, no inquiry is made into the presence or absence of consent. Under sections 30, 9, and 5, this is because the complainant is incapable of consenting. Under sections 34 and 38, it is because any apparent (or, indeed, genuine) consent is vitiated by the inducement, threat, deception, or relationship. $^{20}$

At first blush, the criminal justice statistics reproduced in Table 1 above suggest that, at least in relation to mentally disordered complainants, the 2003 Act has been rather effective in achieving the increased protection sought by the SOR. ${ }^{21}$ The current criminal justice statistics certainly compare favourably with SOR's reported six prosecutions and one conviction for 'sex with a defective' in 1998. However, these data are neither as enlightening nor as reassuring as first appears. 'Sexual Activity etc. with a Person with a Mental Disorder' is an umbrella category covering all the offences contained within sections 30-41 of the SOA 2003. Thus, for example, the figures include offences ranging from penile penetration of a person with severe dementia, right through to the care-worker who plays a blue movie to a person with learning difficulties. Once we recognise that such an array of different offences is included within the category, the number of offences recorded annually actually appears rather low. Even at its highest annual rate, only 163 sexual offences perpetrated against mentally disordered complainants were recorded by police in England and Wales in 2006/07. Intuitively, this cannot accurately reflect the extent of offending against a group which is universally accepted as being particularly

\footnotetext{
18 There is no requirement here that the complainant's mental disorder be such that it impede choice. Indeed, if the complainant is unable to agree, the offence is not made out as no agreement has been obtained, improperly or otherwise, Stevenson et al. (2004, 94). Cf. $R$ v $C$ [2009] UKHL 42 where, in a case prosecuted under section 30, Baroness Hale questions the absence of alternative charges under section 34.

19 Again, it is not necessary under section 38 that the complainant's mental disorder impedes choice.

${ }^{20}$ A marital exception to the care-workers offences is provided in section 43 . Where a sexual relationship between the parties pre-dates one party taking on a caring role, the exception contained in section 44 applies.

21 'Increase' was something of a leitmotif for the SOR. See Home Office (2000a, 0.24, 1.1.1, 1.1.11, 4.5.2, 5.5.11, and 9.2.2).
} 
vulnerable to sexual exploitation and abuse. It may, therefore, be tempting to conclude that the situation reported by the SOR remains true today: that sexual offences committed against persons with mental disorders are seldom reported to police. This is a reasonable assumption. It is, after all, an accepted fact that sexual offences are largely under-reported. ${ }^{22}$ However, (as the male rape study also implies), it would be a mistake to conclude that our inability to see these offences or count their successes in criminal justice statistics means that they are not there. Official statistics obscure at least as much as they reveal about the prevalence of offending and criminal justice outcomes.

We have already seen that a single incident may simultaneously fall within the scope of several different provisions of the SOA 2003. If such allegations were recorded under each and every applicable offence category, police recorded crime would be artificially, and potentially enormously, inflated. Thus, one alleged offence can be recorded only once. ${ }^{23}$ In deciding which crime an incident should be recorded as, the 'record as charged' rule applies. While this sounds like a retrospective categorisation, recording will, in practice, precede charging in many if not most crimes. Hence, in elaborating the 'record as charged' rule, the Home Office Counting Rules specify that the crime recorded 'should be the one with which a suspect would be charged, given the information available at the time of recording. ${ }^{, 24}$ Unfortunately, the ability to identify vulnerability, including mental impairment, is not something for which criminal justice professionals-and the police especially - are renowned ${ }^{25}$ or, indeed, particularly qualified. If, at the time of recording an alleged sexual offence, the police are unaware of a complainant's mental condition, it follows that the incident will not be crimed as one perpetrated against a mentally disordered person.

Following the recent introduction of statutory charging, ${ }^{26}$ the Crown Prosecution Service now determines whether a suspect is to be charged with an offence in all but minor cases and, if so, the appropriate charge. There is obviously room for discrepancies between those charges envisaged by the police at the outset of a case, and those subsequently authorised by the prosecutor-if, indeed, charges are authorised at all. However, further increasing the likelihood of discrepancies is the SOR's intention that what eventually became section 30 of the SOA 2003 'should be an alternative to charging rape but should also provide an alternative verdict in the event of a rape charge not being proved'. ${ }^{27}$ In other words, a defendant may be charged with a section 30 offence instead of rape or, alternatively, he may be charged with offences under both sections 1 and section 30, with the jury left to

\footnotetext{
22 HMCPSI and HMIC (2007, 34); Kelly et al. (2005).

23 See the Home Office Counting Rules for Recorded Crime available online at http://www. homeoffice.gov.uk/rds/pdfs09/countgeneral09.pdf. The National Crime Recording Standard adopted in 2002 is included as an annex to the General Rules.

24 ibid: 'B Classification and Re-classification'.

25 See for example, Burton et al. (2006, 236).

26 Section 10 of the Prosecution of Offences Act 1985; section 37(B) (2) and (3) Police and Criminal Evidence Act 1984 as amended by Part 4, section 29 of the Criminal Justice Act 2003. See further: Brownlee (2004).

27 Home Office (2000a, 4.6.3).
} 
decide if he is guilty of either or neither offence. Thus, the crime for which a defendant is convicted may not tally with the crime that was originally recorded. This has obvious implications for conviction rates.

Conviction rates are estimated by noting how many incidents of a particular offence or crime category were recorded in a crime year, how many convictions for the same crime were recorded in the related (but imprecisely corresponding) sentencing year, and presenting the latter as a percentage of the former. ${ }^{28}$ There is, however, scope for a lack of correspondence between 'offences in' and 'convictions out'. Where an allegation initially recorded as one offence results in a conviction for another, the conviction rates for each offence category will be distorted. In infrequently recorded offence categories, like those set out in Table 1 above, the distortion may be substantial. Even a small proportion of allegations initially recorded as non-consensual offences but which subsequently result in convictions under sections 30-41, will have a marked impact on the latter's conviction rates. This distortion probably goes some way to explaining the comparatively high conviction rate for sexual offences perpetrated against mentally disordered complainants.

Beyond surmising that mentally disordered complainants' allegations of sexual victimisation are entering the system, are being prosecuted, and are resulting in convictions - at least sometimes - it is simply impossible to ascertain the prevalence of such complaints, ${ }^{29}$ or to calculate how often offenders are brought to justice, from such bald and undiscerning data. Moreover, if the criminal justice statistics tell us little about how often sex cases involving mentally disordered complainants are brought to justice, they shed even less light on when, why, and how such cases are (or are not) prosecuted. In order to explore these more searching questions, we need more discriminating data.

\section{Refining the Inquiry}

As noted above, it was the intention of the SOR that the offences contained within sections $30-33$ of the SOA 2003 would operate as a fail-safe ${ }^{30}$ by providing either an alternative charge to a non-consensual offence, or an additional 'in the alternative' charge. However, charging in the alternative does not appear to be a strategy which prosecutors are keen to adopt in practice. In cases involving mentally disordered complainants in the male rape sample, where prosecutors concluded that non-consensual offences could not be proven, no alternative charges followed. Instead, cases were simply discontinued. Equally, where defendants in the male rape study were charged and prosecuted for rape, indictments did not include charges in the alternative for section 30 offences.

\footnotetext{
${ }^{28}$ For persuasive critiques of this crude calculation in relation to sexual offences see: Stern (2010, 9-11, 42-46, 55); Feist et al. (2007, 91); Wolchover and Heaton-Armstrong (2008a, b, c).

29 See also: Lee and Charles (2008).

30 Home Office (2000a, 4.6.3).
} 
The extent to which non-consensual charges in the alternative are similarly omitted when defendants are charged with section 30 offences is unclear. There were no such cases in the male rape study and only four reported cases discuss alternative charges explicitly. The defendant in Attorney-General's Reference 106 of 2005 (Hunter) $^{31}$ was charged with offences under both sections 1 and 30, pleading guilty to the latter. ${ }^{32}$ In Adcock, ${ }^{33}$ three counts of section 30 offences were added to the indictment following plea negotiations: again, Adcock pleaded guilty to these counts and the five counts for non-consensual offences were left to lie on file. The defendants in $R \vee C^{34}$ were initially charged with rape offences, ${ }^{35}$ but were subsequently prosecuted only for section 30 offences. Only in Watts ${ }^{36}$ is it clear that the jury was presented with alternative charges. The silence surrounding alternative charges in the remaining reported cases tends to suggest their absence. ${ }^{37}$

Why are prosecutors apparently reluctant to adopt a strategy which the SOR explicitly designed to allow additional bites at the prosecution cherry? This question was not directly addressed in the male rape study. The study was neither intended nor designed specifically to investigate sexual offending against mentally disordered complainants, or prosecutorial responses to it. And, by the time relevant issues became apparent in the data, it was too late to ask. We can, nonetheless, make an educated guess. Alternative charges were similarly absent in male rape sample cases involving child complainants. In these cases, defendants were typically charged with the relevant non-consensual offences rather than child sex offences. When asked during research interviews why rape charges had been preferred, and in isolation, prosecutors explained that jurors might interpret the availability of alternative counts as reflecting the prosecution's lack of confidence in its case. As one prosecutor elaborated:

It introduces into the jury's mind that you're not confident you can prove that she didn't consent. So it's a very difficult decision to make as to how you frame the indictment and if you're going to have two counts or one. If you can just have the main count, that's what you'd want to do. [Prosecutor G] ${ }^{38}$

\footnotetext{
31 [2006] EWCA Crim 510.

32 Whether a jury would have actually been presented with the alternative counts for non-consensual offences had the case gone to trial is uncertain.

33 [2010] EWCA Crim 700.

34 [2009] UKHL 42.

35 It is interesting to note the differing views of the Court of Appeal and the House of Lords on this issue. The Court of Appeal considered the facts of the case as capable of supporting verdicts under section 1 and 30 of the SOA 2003: $R$ v $C$ [2008] EWCA 1155: [65]. The House of Lords, however, accepted the absence of rape charges and questioned, instead, why the defendant did not face alternative charges of procuring sexual activity with a person with a mental disorder by inducement, threat or deception under Sect. 34: [2009] UKHL 42: [32].

36 [2010] EWCA Crim 1824.

37 Even if this supposition is unwarranted, it does not detract from the observation that alternative charges were certainly absent in the male rape sample cases, and in $R \vee C$.

38 All individuals, locations, and events described in the male rape study are anonymised. The extent of anonymisation goes beyond that required by ethical good practice and data protection in social research, and reflects the sensitive nature of the sample cases and statutory guarantees of lifelong anonymity to rape
} 
Prosecutors also suggested that, faced with alternative charges, a jury would invariably split the difference and opt for the lesser offence-if, indeed, it convicted at all:

If you put rape and section 9 on [the indictment] you're basically telling them, 'I'm not sure [the complainant] is telling the truth. I have a doubt here about him.' So they will either completely acquit of everything or they'll stop with section 9. [Prosecutor H]

Thus, within the male rape study, prosecutors preferred to charge defendants only with non-consensual offences. This was felt to be perceived by jurors as a stronger case, which not only better reflected the nature of the offence alleged, ${ }^{39}$ but also impacted on the penalties available to sentencers. ${ }^{40}$ These were not the only reasons for preferring rape charges, however. Prosecutors are always hopeful that a defendant who initially denies the allegations against him will subsequently change his plea. If alternative charges are included at the outset, such a defendant will undoubtedly opt for the lesser offence. Charging only the more serious of available offences therefore affords the prosecution room to negotiate with the defence should a defendant intimate that he may plead guilty. ${ }^{41}$

It is probable that these same tactical considerations are raised when prosecuting cases involving mentally disordered complainants. ${ }^{42}$ This raises a new question: if prosecutors consciously abstain from charging and prosecuting in the alternative wherever possible and will instead pick $a$-i.e., just one-charge for each separate incident, how do they decide which of a range of potentially applicable offences to charge?

In practical terms, there are three essential pre-requisites to pursuing a case as an offence perpetrated against a mentally disordered person. First, the relevant criminal justice professionals need to be aware that these offences exist. Secondly, those same professionals need to know that a complainant has a mental disorder and, for the purposes of sections 30-33, one which impedes choice. The third pre-requisite is that it is considered appropriate to so charge the offence in the instant case. The first of these elements can be dealt with quickly. We will, for the sake of argument and brevity, assume that criminal justice professionals are all reassuringly familiar

\footnotetext{
Footnote 38 continued

complainants. Cases are referred to numerically, as Case 1 through to Case 17. The prosecutors interviewed are designated Prosecutor A through to Prosecutor $Q$ and are uniformly presented as female. All defendants are referred to simply as $\mathrm{D}$, and complainants as $\mathrm{C}$. Where a case involved more than one complainant, they are again referred to numerically as $\mathrm{C} 1, \mathrm{C} 2$, and so forth.

39 The Code for Crown Prosecutors (2010, 6.1).

40 ibid. Section 1 offences carry a maximum penalty of life imprisonment compared to a maximum penalty of 14 years for offences under Sect. 9.

41 Ashworth and Redmayne (2010, Chapter 10); Sanders et al. (2010, 463-481). Cf. The Code for Crown Prosecutors (2010, 6.3).

42 To the extent that the maximum penalty for both section 1 and penetrative acts under section 30 of the SOA 2003 is life imprisonment, and will subject the defendant to notification requirements, suggesting that the latter is a 'lesser' offence is problematic.
} 
with the relevant provisions of the SOA $2003 .{ }^{43}$ The two further pre-requisites are addressed in turn below. Reflecting the data to hand, the analysis focuses on choosing between pursuing a case as a non-consensual offence or one under section 30. All the male rape study cases-by definition-involved allegations of non-consensual penile penetration. Nine of the eleven reported cases coming under the umbrella of 'sexual activity with a person with a mental disorder' involve prosecutions including charges under section 30 .

\section{Identifying Complainants with a Mental Disorder Impeding Choice}

Clearly, not everyone suffering from a mental disorder will be incapable of consenting to sex. In order to determine whether a complainant falls within the protective scope of section 30, we need first to briefly explore its boundaries and identify any threshold for capacity. ${ }^{44}$ To prove this offence, the prosecution must show that sexual activity occurred; the complainant was unable to refuse because of or for a reason related to a mental disorder ${ }^{45}$; the defendant knew or could reasonably be expected to know that the complainant had a mental disorder and that because of it, or for reasons related to it, was likely to be unable to refuse. ${ }^{46}$ The inability to refuse is further defined as the complainant either lacking the capacity to choose whether to agree to the activity, ${ }^{47}$ or being unable to communicate such a choice. ${ }^{48}$ It is thus not necessary for the prosecution to establish non-consent. As far as sexual activity is concerned, and as the SOR intended, the complainant is untouchable:

The [Sexual Offences] review was unanimously agreed that some people had levels of mental (and sometimes physical) disability so severe that they could not be regarded as being able to give consent in any circumstances. Examples may be those with severe brain damage, severe learning disabilities or severe dementia. Such people would not be able to understand what was being asked of them or to communicate consent, or the lack of it, in any way. An absolute prohibition on sexual relations with such individuals was fully justifiable as essential for their protection. ${ }^{49}$

\footnotetext{
43 This is, unfortunately, unlikely to be the case. Within the male rape sample, a detective investigating an allegation of non-consensual oral penetration in 2007 was apparently unaware initially that this act had been brought within the definition of rape in 2004. It seems rather optimistic to suppose that criminal justice professionals will be uniformly aware of the less frequently invoked provisions of the SOA 2003 if its general and routinely utilised provisions are still being grappled with by some. Lack of familiarity with the new offences among those working with mentally disordered persons has been raised elsewhere: see Home Office (2006).

44 For more comprehensive analyses see: Stevenson et al. (2004).

45 Section 30(1)(c).

46 Section $30(1)(d)$.

47 Section 30(2)(a).

48 Section 30(2)(b).

49 Home Office (2000a, 4.5.3).
} 
Given its deleterious implications for sexual autonomy, the section 30 fail-safe was intended to 'apply to those who indulged in sexual activity with those who were so severely disabled that there was no question that they had the knowledge, understanding or communication skills to consent. ${ }^{50}$ On this basis, the fail-safe appears to be a narrowly targeted exceptional provision. However, whether a mental disorder impedes choice is not a question of law but a question of fact. And a brief analysis of the reported cases indicates that section 30 is far less restrictive in its scope in practice than was envisaged by the SOR. The provision certainly cannot readily be described as being limited to cases involving only 'the most severely mentally disabled' 51

In Hulme, ${ }^{52}$ for example, the complainant was a woman with cerebral palsy and 'a mental age well below her chronological age of 27 years'. 53 Hulme was convicted under section 30 following a contested trial in the magistrates' court. On appeal, it was argued that the complainant had exercised choice-by not consenting-and had communicated her choice to Hulme, who subsequently ignored it; as a vital element of the section 30 offence was missing-i.e., the complainant's mental disorder had not, in fact, impeded choice-the conviction should accordingly be quashed. The Administrative Court disagreed. Having apparently discounted evidence of the complainant's non-consent by confining it to Hulme's request for sexual intercourse, Mr Justice Toulson held that the magistrates had been entitled to find that she was unable to refuse the sexual touching because 'she did not know what to say or do', ${ }^{54}$ which 'could only sensibly be because of her mental condition'. 55

There are three immediate difficulties with this rationalisation. First, if the complainant is capable of (not) consenting to intercourse, she must surely also be capable of (not) consenting to touching. Otherwise we have the absurd proposition that this woman could consent to full penetrative sex with a lover, but not to foreplay. Second, not knowing what to say or do might equally 'sensibly' be explained by the shock and distress of a man groping her genitals, putting her hand on his flaccid penis, and asking for sexual intercourse. The third difficulty is that, in giving their reasons for concluding that the complainant 'lacked the necessary capacity', the magistrates referred to having found that she was incapable of stopping him. ${ }^{56}$ As anyone engaging in sexual activity with somebody bigger and stronger than they are may be physically incapable of stopping the activityregardless of their desire (or otherwise) to do so-this is not an entirely convincing reason for finding someone unable to refuse.

Hulme was clearly deserving of criminal censure and sanction. But he should not have been convicted under section 30. Arguably, Hulme did not engage in sexual

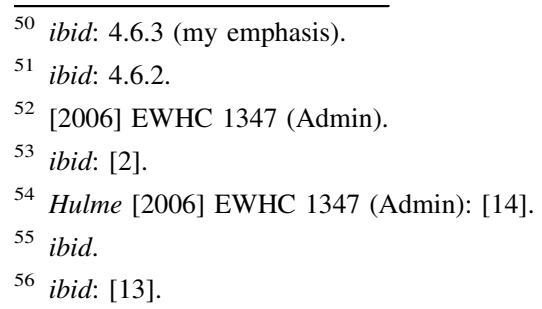


activity with a person who could not consent: he sexually assaulted a person who did not consent. However, Hulme does not appear to have been charged with a nonconsensual offence. As defendants cannot be convicted of crimes for which they do not stand accused, ${ }^{57}$ the only way that the magistrates could convict was to find that the complainant's mental disorder impeded choice. ${ }^{58}$ Given the tenuous reasoning here, it is difficult to avoid concluding that the decisions in Hulme were motivated by the desire to ensure that a defendant who had clearly-and, on appeal, admitted he had-done wrong did not escape justice simply because he had been charged with the wrong offence.

Another troubling case in which a complainant's mental disorder was held to impede choice is Attorney-General's Reference 106 of 2005 (Hunter). ${ }^{59}$ The complainant was a 17-year-old female with mild learning difficulties. Such mental disabilities were never intended to fall within the scope of section 30. Indeed, in recognition of the estimated prevalence of mild to moderate learning disabilities, the SOR explicitly stated that 'it would be unfair and unjust to make sexual activity illegal for all these people' ${ }^{60}$ It was nonetheless accepted, at least by the prosecutor authorising charge and, perhaps, by Hunter himself who pleaded guilty, that the complainant's mental disorder impeded choice. The startling implication of this approach is that approximately $799,830^{61}$ adults over the age of 20 in England alone are prima facie within the 'protective' scope of section 30 .

Widening the net still further is the recent judgment of the House of Lords in $R \mathrm{v}$ $C .^{62}$ Their Lordships held that the jury had been 'entitled to conclude that [the complainant] lacked the capacity either to choose or to communicate within the meaning of the Act'. ${ }^{63}$ This 'either/or' fudge is unconvincing. While the opinions of the psychiatric practitioners called by the Crown appear to differ to some extent on the issue of whether the complainant was able to exercise choice, the complainant's own evidence stated quite categorically that she did not consent to the sexual activity. ${ }^{64}$ To be sure, complainants' accounts cannot be determinative on the issue of capacity. Nevertheless, we should be reluctant to dismiss a complainant's vehement and consistent statements of non-consent in order to find that she was unable to choose. Arguably, the defendants, the prosecutor, and the courts all, in their own ways, failed to take this complainant's sexual autonomy seriously. Apparently, not only could this complainant choose, she did choose: she did not consent.

Fearing for her life, however, the complainant did not communicate her nonconsent to the defendants. If her silence on this issue was a manifestation of her

\footnotetext{
57 Criminal Law Act 1967, section 6.

58 In addition, of course, to finding that the other elements of the offence were also made out.

59 [2006] EWCA Crim 510.

60 Home Office (2000a, 4.1.5).

61 Emerson and Hatton (2004). This 'conservative estimate' is predicted to rise to 867,523 by 2011.

62 [2009] UKHL 42.

63 [2009] UKHL 42: [32] (my emphasis).

64 The complainant's evidence was quoted fairly extensively by Lord Phillips CJ in the Court of Appeal judgment: $R$ v $C$ [2008] EWCA Crim 1155.
} 
mental disorder, then, unable to communicate, she could not refuse and thus fell fairly and squarely within the scope of section 30. This conclusion seems unobjectionable. Yet, the complainant here was cornered in the bathroom of a stranger's house by two intoxicated men, one of whom had already relieved the complainant of her mobile 'phone and bicycle, plying her with crack-cocaine and demanding sex. Attributing the complainant's non-communication in these circumstances to her mental disorder, rather than to the defendants' behaviour, is questionable to say the least. This complainant was not, one might think, momentarily ${ }^{65}$ too mad to consent or communicate. Rather, she was repeatedly raped. $^{66}$

Following $R$ v $C$, whether a mentally disordered complainant is unable to refuse is not merely issue-specific, as the Court of Appeal ${ }^{67}$ had previously held, but is also person-specific and situation-specific. Superficially, Baroness Hale's reasoning appears persuasive: '... It is difficult to think of an activity which is more person and situation specific than sexual relations. One does not consent to sex in general. One consents to this act of sex with this person at this time and in this place. ${ }^{68}$ Yet, such a flexible, context-specific approach risks transforming the offence from 'sexual activity with a person with a mental disorder impeding choice' into 'sexual activity, with a person with a mental disorder, in circumstances which impede choice'. This is problematic for two reasons. First, such factors-and especially those at play in $R \vee C$-fall within the realm of section 74 of the SOA 2003, the presumptions against consent in sections 75 and 76, and thus implicate nonconsensual offences. ${ }^{69}$ Second, as we have already seen, section 30 is not confined to persons with severe mental disorders.

Although generous interpretations of section 30 have undoubtedly facilitated the conviction of defendants who might otherwise have avoided criminal censure, the expansive and inclusive approach to its application observed in these cases is objectionable. In practice, the threshold for the applicability of section 30 is virtually non-existent: a complainant's mental disorder impedes choice when factfinders say it does. ${ }^{70}$ And the cases outlined here suggest that fact-finders may be readily persuaded on this issue; especially, it seems, in the absence of charges for non-consensual offences. However, section 30 'protects' mentally disordered

\footnotetext{
65 Baroness Hale opined that, at the material time, the complainant may have had the capacity to consent under different circumstances: $R$ v $C$ [2009] UKHL 42: [26].

${ }^{66}$ It is worth noting that, in proving rape, the law does not require a complainant to demonstrate or communicate their non-consent to a defendant. There must, however, be evidence of lack of consent to go before the jury (Malone [1998] $2 \mathrm{Cr}$ App R 447). Such evidence was very clearly available to the prosecution here. It therefore seems reasonable to infer that the prosecutor in this case considered it easier to prove that the complainant could not consent than it was to prove that she did not consent. This proposition was given rather short shrift by Baroness Hale: [32]. See also: Herring (2010, 38). Cf. Maher (2010, 132).

${ }^{67} R$ v $C$ [2008] EWCA Crim 1155.

${ }^{68} R$ v $C$ [2009] UKHL 42: [27].

69 See also Herring (2010, 38); Maher (2010, 131).

70 Psychiatric opinion is not determinative on this issue. Indeed, in Hulme [2006] EWHC 1347 (Admin) [20] it was stated that it is not even necessary to present fact-finders with expert evidence on this issue.
} 
complainants from unwanted sexual activity by denying, or at least diminishing, their right to engage in sexual activity per se. Its provisions are disempowering and dehumanising. The courts should therefore be reluctant to allow great swathes of the adult population to be brought within the scope of such capacious provisions-even if that means accepting that some defendants may avoid criminal liability under the general provisions of the SOA 2003 for want of proof on the issue of non-consent. ${ }^{71}$

In countering this claim, it is not enough to say that, since the law would not be invoked without an allegation of sexual offending from such persons, the sexual autonomy of adults with mental disorders remains intact in practice if not in law. Within both the male rape sample and the section 30 cases in the law reports, complaints to police were frequently made by third parties, and not by victims themselves. This is nothing out of the ordinary. In a recent large-scale analysis of rape in the criminal justice system, $46 \%$ of rape allegations recorded by police were reported by third parties. ${ }^{72}$ Given the increased care and supervision encountered by mentally disordered persons either in institutions or in the community, it does not require much imagination to suggest that their private lives may be less private than 'the norm' and that a protective parent or cautious carer may be inclined-perhaps even duty-bound - to inform the police of any sexual activity about which they become aware, or suspect may be taking place. If the victim has a mental disorder then there is a potential section 30 case, regardless of who made the initial complaint.

Yet, this claim presents a further puzzle. Assuming, as we are, that criminal justice professionals are fully versed in the relevant offences and developing caselaw, and given the prevalence of mental disorder among the sexually victimised population, why are there so few section 30 cases in the criminal justice system? Why are prosecutors not chancing their arm with section 30, and avoiding the tricky business of proving non-consent, in any case involving a mentally disordered complainant? Empirical evidence demonstrating that police and prosecutors are often unaware of complainants' vulnerability, including mental impairment, doubtless provides part of the explanation. Put bluntly, generous interpretations of what constitutes a mental disorder impeding choice are of little consequence if criminal justice professionals remain unable to identify mentally disordered complainants.

However, this factor alone cannot fully explain the apparent shortfall in section 30 cases brought each year. After all, in the six relevant cases from the male rape sample, police and prosecutors were aware of complainants' mental conditions but section 30 charges still did not follow. In our quest for some other explanatory factor or factors, we must turn to the third dimension of charge selection: namely, which charge, if any, is considered appropriate in the instant case.

\footnotetext{
71 As Maher $(2010,132)$ argues, 'making easier an element of the proof by the Crown of the accused's guilt is hardly a good basis for making separate offences (in effect labelling rape as something other than rape). It should rather be a consequence of some principled separation out of the offences.'

72 Feist et al. (2007, 23). A more recent study found just over 25\% of rape complaints to Metropolitan police were reported by third parties: Stanko and Williams (2009).
} 


\section{Selecting an Appropriate Charge}

Confronted with a case involving a complainant suffering from a mental disorder, how do prosecutors decide whether to pursue non-consensual or section 30 charges? This question was not raised directly with prosecutors during research interviews in the male rape study. Nevertheless, an analysis of the cases themselves sheds some light on prosecutors' implicit decision-making rationales. By comparing and contrasting the cases, it is possible to identify factors which are common to prosecuted cases but absent in unprosecuted cases. Distinctions can then be tentatively drawn between complaints which proceeded as rapes and those prosecuted under section 30. We consider first those cases from the male rape study, which were charged and ultimately prosecuted as rapes.

\section{Prosecuting Rape}

In Case $1^{73}$ from the male rape study, the complainant, $\mathrm{C}$, was violently anally raped in his home one evening by the casual sexual partner of C's homosexual landlord, who was also present throughout the incident. The police were called immediately. $\mathrm{C}$ had suffered significant and extensive injuries during the incident requiring immediate hospital treatment. In addition to C's consistent accounts to police and doctors, prosecution evidence included: medical reports; photographic evidence of C's (horrendous) injuries; the statements of several police personnel attesting to C's distressed, bruised and bloody state in the immediate aftermath; a letter sent to the complainant by $\mathrm{D}$ whilst on remand which included various admissions, threats, and apologies; and, of course, an eye-witness account of the assault in its entirety.

The prosecutor was aware that, in addition to ongoing alcohol and drug abuse, $\mathrm{C}$ had a history of mental health problems. However, whether and to what extent C's mental condition might have impacted upon his ability to consent at the material time does not appear to have even been considered. In addition to C's statements, a substantial body of independent evidence powerfully testified to a violent sexual assault. There was simply no question that $\mathrm{D}$ would be charged with anything other than rape. On the first day of trial, D abandoned his consent defence and pleaded guilty as charged.

In Case 6, $\mathrm{C} 1$ 's historic allegation of anal rape ${ }^{74}$ at knife point triggered the initial investigation and subsequent prosecution of $\mathrm{D}$ for non-consensual sexual offences perpetrated against three complainants. Due to the twenty-plus year delay in reporting the offence, no medical or scientific evidence was available. However, C1's account was consistently supported by a series of disclosures he had made to third parties over the years. Following D's arrest, a sample of his DNA was profiled and loaded on to the National DNA Database. This profile matched crime samples retrieved from the unsolved kidnap and sexual assault of a pre-pubescent male, C2,

\footnotetext{
73 See n.38 above.

74 Although section 30 charges would not have been available in this pre-2003 Act case, the factual scenario it presents nevertheless remains pertinent to the present analysis.
} 
in the 1990s. When the local press reported D's bail hearing, a third male, C3, contacted police to report an historic incident of rape perpetrated by D. ${ }^{75}$ The three incidents were joined on a single indictment.

$\mathrm{C} 1 \mathrm{had}$ mild to moderate learning disabilities and had suffered with anxiety and depression for much of his life. During our research interview, the prosecutor made no mention whatsoever of C1's mental disorder(s), or any impact that this might have on the issue of consent or his ability to provide perceptively accurate, reliable and credible testimony in court. Instead, Prosecutor $A$ reported being "very confident' regarding the case against D as there were 'quality' statements from three complainants who were each considered to be compelling witnesses: three unacquainted complainants, moreover, who all effectively and independently corroborated one another. Having had his attempt to bargain on the facts ${ }^{76}$ emphatically rejected by the prosecution, D pleaded guilty as charged on all counts.

In contrast to Cases 1 and 6, the defendants in Cases 13 and 14 were convicted by juries following full contested trials. Both cases involved multiple-count, multiplecomplainant prosecutions relating to various sexual acts perpetrated, in each case, by a single defendant. The ${ }^{77}$ male rape complainant in Case 13 was described in the prosecution case-file as having learning difficulties, special needs, and a speech impediment. In Case 14, the two male rape complainants ${ }^{78}$ were noted as having mental health difficulties: one having 'slight' learning disabilities; the second simply as being 'in therapy'. Owing to the delays in reporting these incidentsranging from several days to twenty-plus years-there was no medical or scientific evidence available in either Case 13 or 14 . Instead, both prosecutions relied almost entirely on complainants' accounts.

Prosecutor $J$ had dealt with both cases. During our research interview, the only reference she made to complainants' mental disorders concerned the ability of $\mathrm{C} 1$ in Case 13 to give his evidence in the courtroom, prompting an application for a special measures direction ${ }^{79}$ :

[C1] was the only male [rape] victim but we had got very compelling evidence in relation - and he was the most vulnerable I think. The most vulnerable of all the witnesses in the sense that he'd got all sorts of difficulties. There were going to be problems in him presenting his evidence because he'd got a very severe speech impediment. [Prosecutor J]

\footnotetext{
75 A fourth male also contacted police alleging sexual victimisation by D. However, this male would not cooperate with a prosecution and refused to make a statement.

76 The defendant initially offered to plead guilty if particular aggravating factors were omitted from the statement of facts, in particular: the presence of the knife during the rape of $\mathrm{C} 1$; and, the physically picking and taking away of $\mathrm{C} 2$. For a discussion of fact bargaining, see: Ashworth and Redmayne (2010, 300-301); Sanders et al. (2010, 485-486).

${ }^{77}$ There were six complainants in Case 13, four of whom were female. The second male complainant in the case did not allege rape.

${ }^{78}$ Five males made allegations of sexual victimisation against the defendant in Case 14, two of whom alleged rape.

79 Section 27 of the Youth Justice and Criminal Evidence Act 1999. See further Home Office (1998, 2000a, 2007).
} 
The 'compelling evidence' in Case 13 to which the prosecutor referred was precisely the same compelling evidence available in Case 14: the independent, corroborative testimony of multiple complainants.

It has to be right that if you've got more than one victim, you're likely to have a stronger case. [Prosecutor J]

While the facts and circumstances of Cases 1, 6, 13 and 14 differ, a common feature is immediately apparent: in proving its case, the prosecution was not reliant solely on the courtroom testimony of a lone complainant. Instead, probative evidence was available to the prosecution which was independent of individual complainants, mentally disordered or otherwise. Put simply, these were not cases which pitted one-i.e., only one-person's word against another's.

As regards charge selection, pursuing defendants for offences under section 30 - or, where applicable, the relevant child sex offences-would reflect neither the nature and circumstances of the acts alleged, nor the available supporting evidence. In addition, these cases tend to add credence to prosecutors' claims that additional charges in the alternative potentially undermine the prosecution's case at trial. It is not difficult to see that simultaneously arguing that the complainant in Case 1, for example, could not refuse, when potent evidence corroborates C's statements that he absolutely and categorically did refuse, might muddy the waters for fact-finders.

\section{Prosecuting Section 30}

We turn now to the reported section 30 cases, in an attempt to identify any similarities or differences with those cases prosecuted as rape. Of the nine ${ }^{80}$ cases in the law reports involving, inter alia, charges under section 30, defendants pleaded guilty in four cases and were found guilty following a full contested trial in five. We will analyse the guilty plea cases and then the trial cases, both taken in chronological order (as reported).

In $R v D,^{81}$ D's partner entered the kitchen of their shared home to find $\mathrm{D}$ touching her mentally disordered 25 year old grand-daughter's vagina. ${ }^{82}$ Little is disclosed about the nature of the complainant's mental disorder in the judgment, save that she had a mental age of between four and eight years and was sexually unaware. Following his arrest, D initially denied the offence outright. However, presumably having realised that his partner-an eye-witness to the incident-was willing to testify against him, and having previously been cautioned for a similar offence perpetrated against the same complainant, ${ }^{83} \mathrm{D}$ subsequently pleaded guilty to one count contrary to section 30 .

\footnotetext{
${ }^{80}$ As noted in the introductory paragraphs, eleven cases involving sexual activity with a person with a mental disorder were reported at the time of writing (September, 2010). Two of these cases, however, ( $R$ v Bradford [2006] EWCA Crim 2629; $R$ v Jones (Gareth William) [2009] EWCA Crim 237) involve charges under section 38 rather than section 30. As such, they are not subject to detailed analysis in this article.

81 [2005] EWCA Crim 1459.

$82 \mathrm{D}$ and the complainant were not blood relatives.

83 (Probably) now admissible under section 101 of the Criminal Justice Act 2003.
} 
The complainant in Attorney-General's Reference 106 of 2005 (Hunter) ${ }^{84}$ was a 17 year old female with mild learning difficulties. She disclosed to her mother that she had engaged in various sexual acts including vaginal and oral penetration with Hunter - a friend of her mother's - some months after the acts had taken place. The mother's initial reaction was disbelief. However, the complainant had previously told a neighbour of the sexual activity. So, too, had Hunter. When arrested and interviewed by the police, Hunter admitted that sexual activity had occurred but claimed that all activity was consensual and had been instigated by the complainant. Charged with three counts each of section 1 rape and section 30 offences in the alternative, Hunter pleaded guilty to the section 30 charges.

In the third of the reported guilty plea cases, $R \mathrm{v} C$ (Peter Charles), ${ }^{85}$ the complainant, a 20 year old woman with Downs Syndrome, disclosed sexual activity with a neighbour to her parents, who immediately informed the police. Following his arrest, the defendant admitted the sexual acts, including digital and oral penetration, alleged. He was charged with, and pleaded guilty to, six counts contrary to section 30. No mention is made in the judgment of charges for non-consensual offences under sections 1 to 3 .

The final reported section 30 case in which the defendant pleaded guilty is $R \mathrm{v}$ Adcock. ${ }^{86}$ The defendant's wife was a long term resident in a care home where Adcock visited her on an almost daily basis. As his wife was unable to communicate, Adcock frequently visited with other residents at the home. The incident sparking the investigation was witnessed by two care assistants. They saw Adcock sitting in the lounge with another female resident, BG, who had previously suffered a severe stroke and noted that sexual touching was taking place. The manager was informed and the police were called.

When interviewed under caution, Adcock admitted the acts witnessed by the care assistants. He also admitted to previous sexual activity with BG. He maintained that this activity was consensual and at BG's instigation. Other evidence confirmed that BG was sexually disinhibited ${ }^{87}$ and that 'she made sexual demands from time to time of those around her. ${ }^{88}$ Initially charged with five counts for non-consensual offences, three section 30 charges were later added to the indictment following plea negotiations. ${ }^{89}$ Adcock pleaded guilty to these three counts; that BG had initiated and encouraged the sexual activity was included in the basis of plea. ${ }^{90}$ The five nonconsensual offences were left to lie on file.

\footnotetext{
${ }^{84}$ [2006] EWCA Crim 510.

85 [2007] EWCA Crim 2266.

86 [2010] EWCA Crim 700.

${ }^{87}$ ibid: [4], [12].

${ }^{88}$ ibid: [18].

${ }^{89}$ ibid: [7]. Counts 1-5, the non-consensual offences, were left to lie on file.

90 ibid: [8].
} 
There are five reported section 30 cases in which defendants denied all allegations but were nonetheless convicted following trial. In Jones, ${ }^{91}$ the offence took place at a public house during opening hours. The complainant was a 19 year old male with Downs Syndrome and a mental age of approximately 5 years. Eyewitnesses to events included the complainant's brother, his sister, the pub landlord, and the crowd of customers who had set upon Jones when he was discovered with the complainant. Although assessed as a competent witness, the complainant did not testify at trial. Instead the prosecution adduced the testimony of several eyewitnesses and CCTV recordings to prove the offence that Jones claimed not to remember. He was convicted of sexual activity contrary to section 30 . There is no mention in the judgment of any non-consensual offences being charged in the alternative.

The sexual acts complained of in Hulme $e^{92}$ were also perpetrated in a public house during opening hours. Seeing what was taking place, a customer intervened, led the complainant away to her parents - the landlords of the pub - and told them what had occurred. Although, as discussed above, evidence of non-consent was available to the prosecution in this case, and was adduced at trial, the defendant does not appear to have been charged with a non-consensual offence. Rather, the prosecution seems to have proceeded on the basis that the complainant could not rather than did not consent.

The sexual touching alleged in Perera $^{93}$ was witnessed and reported by a fellow nurse in the residential care home in which Perera worked. The complainant was a female resident in her mid-seventies with severe dementia and difficulties of comprehension, expression and speech. She was said to be unable to make meaningful conversation and unable to consent. The complainant was not called as a witness at trial. ${ }^{94}$ Indeed, it is unlikely that she had even provided the police with a statement. In his police interview, Perera denied the allegations outright, stating that his nursing colleague had fabricated the complaint because she thought that Perera had reported her for being late for work.

Evidentially, Perera was a straightforward case of one person's word against another's. However, it was not the mentally disordered complainant's word upon which the prosecution relied, but that of the independent eye-witness. What is perhaps revealing about the prosecution's implicit assessment of the strength of the evidence in this case is that Perera was not prosecuted for the less serious careworker offence under section $38 .{ }^{95}$ On the other hand, however, neither does he appear to have been charged with non-consensual offences. ${ }^{96}$

\footnotetext{
91 [2005] EWCA Crim 3414.

92 [2006] EWHC 1347 (Admin).

93 [2007] EWCA Crim 3277.

94 One assumes that this complainant would not be a competent witness under section 53 of the Youth Justice and Criminal Evidence Act 1999.

95 As the sexual activity in Perera was non-penetrative, the section 38 offence carries a maximum sentence of 10 years in contrast to 14 years following a conviction on indictment for a section 30 offence.

96 Arguably, the complainant in Perera was 'self-evidently' incapable of consenting to sexual activity. Potentially, the defendant could therefore also have been charged with sexual assault contrary to
} 
In the fourth contested case, $R \vee C,{ }^{97}$ the complainant suffered from schizoaffective disorder, emotionally unstable personality disorder (borderline type), had an IQ below 75, and was 'subject to harmful use of alcohol.' 98 She had been hospitalised on several occasions but, following a period of mental stability, was living in a hostel in the community under a supervised discharge order. ${ }^{99}$ She was considered to be in relapse at the time the offences were committed. The first defendant had encountered the complainant in an agitated and distressed state outside the hostel and again, later the same day, walking along a road. Under the guise of a Good Samaritan, he befriended the complainant, sold her mobile telephone and bicycle (retaining the money) and took her to the second defendant's house. Having trapped her in the bathroom and plied her with crack-cocaine, both defendants engaged in multiple penetrative sexual acts with the complainant.

At trial, the complainant's evidence-in-chief was adduced in the form of her ABE video interview with police, ${ }^{100}$ followed by live cross-examination. Her apparently vivid and detailed evidence included several very clear statements that she did not want to engage in sexual activity with the defendants. ${ }^{101}$ Indeed, her evidence on this issue was so persuasive that, in giving the judgment of the Court of Appeal, Lord Phillips CJ stated that "properly presented the facts of this case might have been capable of supporting the verdicts of offences under section 1 or section 30 of the 2003 Act. ${ }^{102}$ However, while the defendants had initially been charged with rape, these charges were dropped prior to trial with section 30 charges 'substituted at a late stage., 103

The final and most recently reported case is Watts. ${ }^{104}$ The defendant was a care worker in a residential care home. Again, the investigation and prosecution was sparked by a co-worker witnessing Watts sexually touching one of the residents. The police investigated, whereupon further and more serious allegations came to light. Watts was charged with sexual offences perpetrated against four female complainants; all residents in the home in which he worked. Three of the complainants, TB, JR, and JB, had cerebral palsy, the various and varying physical and cognitive effects of which are discussed at several points in the court's

\footnotetext{
Footnote 96 continued

section 3. See also, $R$ v Gareth William Jones [2009] EWCA Crim 237 involving charges under section 38 rather than section 30 or, indeed, section 2 (if not section 1).

97 [2009] UKHL 42. It should be noted that the earlier judgment of Court of Appeal provides a more detailed discussion of the available evidence. Consequently, it is frequently referred to in the analysis here.

$98 R$ v $C$ [2008] EWCA Crim 1155: [4].

99 ibid: [5].

$100 \mathrm{ABE}$ video interviews are those conducted pursuant to the current Achieving Best Evidence policy and their use as evidence-in-chief is governed by section 27 of the Youth Justice and Criminal Evidence Act 1999. See also: Home Office (2000b, 2007)

101 Her testimony is referred to extensively in the Court of Appeal judgment: $R$ v $C$ [2008] EWCA Crim 1155. See, in particular: [13] and [17].

102 ibid: [65].

103 [2009] UKHL 42: [32].

104 [2010] EWCA Crim 1824.
} 
judgment. All three had significant difficulties communicating. The fourth complainant, SC, suffered from spastic tetraplegia. At the time she made her complaint, and in comparison with the three other complainants, SC was described as being relatively intact cognitively. ${ }^{105}$ However, SC subsequently suffered a stroke and, when the case came to trial, she was unable to speak or otherwise communicate.

In relation to the section 30 offence involving the touching of TB's breast, the evidence appears to have been confined to the courtroom testimony of the eyewitness. In relation to JR, JB, and SC, the prosecution's case seems to have rested in large part, if not entirely, on their ABE video interviews, adduced as evidence-inchief. ${ }^{106}$ These accounts were not without their problems. Inter alia, the jury was informed of other, demonstrably false, allegations made by JR in the course of her ABE interviews; that JB was highly suggestible and likely to be compliant in her answers; that there was no evidence that Watts had ever been alone with JB; and that SC had a manifest tendency to confabulate and that confabulation was clearly apparent in many parts of her pre-recorded evidence.

Watts was indicted on thirteen counts. In relation to TB, he was charged and prosecuted for one count of sexual touching under section 30 . Three counts contrary to section 38 related to JR: count 2 was non-penetrative; counts 3 and 4 , penetrative. In relation to JB, Watts faced four charges, again, under section 38: two charges were for digital penetration (counts 5 and 6); and two charges for penile penetration (counts 7 and 8). Finally, in relation to SC, there were two counts of sexual assault contrary to section 3 (counts 9 and 10), and three counts of rape under section 1 (counts 11, 12 and 13). Although Watts was convicted, the jury does appear to have 'split the difference' between the available charges, to some extent, in line with prosecutors' reported perceptions. Guilty verdicts were returned on the lesser charges contained in counts 1 , $2,5,6,9$ and 10 . The remaining counts all resulted in acquittals.

Identifying the features or characteristics that distinguish a non-consensual offence from one pursued under section 30 is complex. The analysis so far suggests that the section 30 cases fall into three broad categories which split, essentially, on the issue of consent. First, there are cases where complainants were severely mentally disabled and self-evidently unable to consent. Such cases are exemplified by Perera ${ }^{107}$ and Watts. ${ }^{108}$ Second, are those cases where complainants appear not to have consented-in the positive sense. $R$ v $C^{109}$ would be the most powerful example here. Finally, there are those cases where consent is more ambiguous; perhaps most readily exemplified by Adcock. ${ }^{110}$

At first blush, differentiating the section 30 cases in this way is unhelpful and unpersuasive: if a complainant was unable to refuse then there was no consent, and all the section 30 cases are effectively 'the same'. Moreover, a complainant who

\footnotetext{
105 ibid: [6].

106 n.100 above.

107 [2007] EWCA Crim 3277.

108 [2010] EWCA Crim 1824.

109 [2009] UKHL 42.

110 [2010] EWCA Crim 700.
} 
cannot consent for the purposes of section 30, presumably, cannot consent for the purposes of sections 1 through 4 either. Section 74 provides that 'a person consents if he agrees by choice, and has the freedom and capacity to make that choice.' To the extent that a defendant has engaged in sexual activity with a person who was not consenting, the conduct elements of the section 30 and the corresponding nonconsensual offence are also indistinguishable.

The mentes reae, however, are subtly but crucially different. In prosecuting a non-consensual offence, the prosecution must, inter alia, prove beyond reasonable doubt that the defendant did not reasonably believe that the complainant was consenting. Prosecuted under section 30, however, the requisite mens rea is that the defendant: i) knew or could reasonably be expected to know that the complainant has a mental disorder; and, ii) that because of it, or for a reason related to it, the complainant was likely to be unable to refuse. ${ }^{111}$ In a case where the complainant is a fragile old lady with severe dementia and whose communicative abilities are nil, or effectively nil, then the difference is, arguably, inconsequential. (Indeed, one may wonder why it was considered necessary to create the section 30 fail-safe to cover this scenario in the first place.)

In contrast, in a case like Adcock, where evidence was available which strongly suggested that sexual activity had at least the appearance of being consensual, proving that a defendant's belief in consent was not reasonable may be somewhat more tricky. The difficulties posed by the 'ostensible consent' case are avoided, however, when the defendant is prosecuted under section 30. Certainly, the reported cases analysed here suggest that where the available evidence provides even a hint of consent-in-fact, then, if the case proceeds at all, it will likely be pursued under section 30 .

This, in turn, raises the prospect of over-criminalisation. As originally conceived, section 30 was intended to be confined in its application to the most severely and profoundly mentally disordered complainants. Given that it is not so restricted in practice, there is a salient debate to be had regarding whether the defendant who engaged in sexual activity with a mentally disordered complainant-and recall that this includes an adult with mild learning difficulties - and reasonably believed that she was consenting has actually done anything wrong.

Nevertheless, the issue of consent appears to be of limited assistance in distinguishing between those cases prosecuted as rapes and those pursued under section 30. Looking for similarities among the cases rather than differences, however, sheds rather more light on prosecutors' implicit rationales for charge selection. Despite their factual and circumstantial differences, the section 30 cases share a common evidential feature which was also identified in the relevant prosecuted rape cases from the male rape sample surveyed above. As in the rape cases, none of the prosecuted section 30 cases relied solely-and in some cases, did not rely at all-on the courtroom testimony of $a$-i.e., just one-mentally disordered complainant. Indeed, in six of the nine section 30 cases analysed here, there was at least one eye-witness to events.

111 Section 30(1)(d). 
It appears, therefore, that where complainants' claims of non-consent were independently corroborated, defendants were prosecuted for rape. In contrast, where corroborative evidence was (from what can be gleaned from the law reports) limited to establishing the occurrence of sexual activity, the case was prosecuted under section 30. Thus, the factor which seems to determine whether the case will be prosecuted as rape or under section 30 is the prosecutor's implicit assessment of the evidential strength of the case rather than the presence or absence of consent, or the defendant's reasonable belief therein. More crucially, however, the cases analysed here suggest that section 30 may be utilised by the prosecution as a device for manipulating and effectively bolstering the evidential strength of a case.

$R$ v $C$ provides the most striking example. In the course of their police interviews, the defendants appear to have admitted to engaging in penetrative sexual acts with the complainant but claimed that the acts were consensual. There was, for example, a notable absence of discussion surrounding scientific or (non-psychiatric) medical evidence in the judgments of both the Court of Appeal and the House of Lords. Given that the complaint was made fairly promptly, the absence of such evidence only really makes sense if the fact that sexual activity had taken place was not in dispute.

In addition, the grounds of the appeal were predicated on the assumption that the complainant had, in fact, consented to the activity and/or that the defendant reasonably believed she had. Thus, had the defendants been prosecuted for rape, consent would have been a contested issue. And, on this issue, the evidence boiled down to the complainant's word against the denials of the two defendants. By substituting the original rape charges with section 30s, the prosecution, in one fell swoop, dispensed with the need to rebut the defendants' consent defence and avoided relying solely on the complainant's testimony in proving its case.

However, it has long been a principle of English law that 'those who are arrested in respect of an offence are entitled to know where they stand'. ${ }^{112}$ This principle is reflected in the Police and Criminal Evidence Act $1984^{113}$ and its related Codes of Practice, ${ }^{114}$ as well as in Article 5 of the ECHR. A suspect must be informed, at least in general terms, of the nature and level of the offence for which he is under investigation. To the extent that the defendants in $R$ v $C$ were clearly aware from the outset that they were suspected of committing serious sexual offences, this principle appears to be satisfied. Nevertheless, it is far from obvious that the defendants - or their solicitors-were aware that section 30 was one of the offences in play. ${ }^{115}$

On the supposition that the defendants were not cautioned in relation to section 30 until they had already tacitly admitted the actus reus of that offence in the course of raising a consent defence to the alleged rapes, then the late substitution of charges might be viewed as shifty rather than nifty prosecutorial practice.

\footnotetext{
112 Kirk [2000] 1 WLR 567: 571; Christie v Leachinsky [1947] AC 573.

113 Section 28

114 Code C, Section 10; Code G, Section 2.

115 While the potential applicability of section 30 may only come to light during the course of an investigation that was not the case here. The complainant's mental health problems were apparent to the police even before she made her complaint. See Baroness Hale's speech in $R$ v $C$ [2009] UKHL 42: [20].
} 
Moreover, this prosecutorial strategy of hoisting defendants with their own petards is also suggested by the events which unfolded in the cases of Hunter, Adcock and $R$ v $C$ (Peter Charles). Certainly, the defendant's admissions were critical in securing convictions in these cases.

That the prosecutor's implicit assessment of the evidential strength of the case is a determinative factor in charge selection and case progress is a relatively prosaic observation and one which should not come as much of a revelation. Nor should it be especially contentious. The positive relationship between independent evidence, prosecution, and conviction is not unique to sex cases involving mentally disordered complainants. Similar patterns are reported elsewhere in relation to female rape, ${ }^{116}$ and, moreover, in attritional studies encompassing all crimes. ${ }^{117}$

This does not mean that cases which, in evidential terms, effectively boil down to one person's word against another's will never proceed. Indeed, Perera is one counter-example. Nevertheless, the correlation between independent evidence and prosecution reported elsewhere is clearly apparent here. Which suggests that, despite being heralded as a fail-safe, the utility of section 30 is distinctly limited in practice. Again, this claim is best demonstrated with concrete examples rather than simply stated in the abstract. We turn, therefore, to the two cases from the male rape sample which failed to result in a prosecution.

\section{Deciding not to Prosecute}

The complainant in Case 17-a male in his late twenties with 'mild to moderate learning difficulties' - was allegedly raped by a lodger as he slept in the family home. The incident was witnessed in part by C's elder brother who, having entered C's bedroom to check on him during the night, found C and D in a state of undress. The incident was reported to police by C's brother almost a year later. Consequently, no medical or scientific evidence was available. Following his arrest, D denied that any sexual activity had occurred whatsoever. On the basis of C's clear and partially corroborated complaint of non-consensual penetration, D was charged with rape and the case was sent for trial.

$\mathrm{C}$ had presented no communication difficulties during the course of the investigation. Neither his family, nor those professionals working with $\mathrm{C}$, had alerted the police or prosecutor to any communication difficulties which $\mathrm{C}$ might display. On the day of trial, however, the complainant either could not or would not speak. Prosecuting counsel immediately made a special measures application to have C's video-recorded police interview adduced as his evidence-in-chief. ${ }^{118}$ Defence counsel opposed this on the ground that, since $C$ was now mute, he could not be cross-examined, thus denying the defendant a fair trial. This was accepted by the trial judge and the special measures application was denied. Unable now to

\footnotetext{
116 Brown et al. (2007); Feist et al. (2007).

117 Phillips et al. (1998); Burrows et al. (2005).

118 Section 27 of the Youth Justice and Criminal Evidence Act 1999. The recording may not be admitted if $\mathrm{C}$ is unavailable for cross-examination and there is no agreement between the parties that $\mathrm{C}$ does not need to be available for cross-examination.
} 
prove the requisite elements of the offence, prosecuting counsel terminated the case by offering no evidence.

Arguably, and in light of the above, C's mental disorder was sufficient to bring him within the scope of section 30. Indeed, although Prosecutor $M$ never discussed section 30 explicitly during our research interview, she had expressed some doubts over whether $\mathrm{C}$ had the capacity to consent to sex:

It was still a case that had to be run because one thing I'll never know is whether his learning difficulties were such that it actually prevented him from consenting.

Nevertheless, charging section 30 would not have facilitated D's prosecution in this instance. While the absence of consent need not be proved under section 30, it remains necessary to prove that sexual activity occurred. As $\mathrm{C}$ was unable or unwilling to testify to this-or any other-issue, proving the basic conduct element of the offence would require another source of evidence. And, there was none: there was no scientific or medical evidence; the brother had surmised but not seen any penetrative sexual activity; and, unlike the defendants in, for example, $R \vee C$, and Adcock, the defendant in Case 17 consistently and categorically denied any sexual contact.

Case 17 brings the limitations of section 30 into sharp focus. The fact that it is not necessary to prove the absence of consent is of little consequence if the prosecution is unable to prove the rest of its case. Echoing the sentiments of Mencap, ${ }^{119}$ if the complainant can't tell, and the defendant won't admit it, then, in the absence of independent evidence, there will be insufficient evidence for a prosecution under either section 1 or section 30. Arguably, the relevant provisions of the SOA 2003 have done little to increase the protection afforded to mentally disordered complainants in sex cases as they fail to address the principal, and very practical, forensic obstacles to securing convictions in these cases: the need for reliable prosecution evidence on all the elements of the offence charged. ${ }^{120}$

That the main stumbling block here is the reliability of evidence, rather than simply its independence, is highlighted by the second unprosecuted male rape case involving a mentally disordered complainant. The complainant in Case 8 reported that he had been orally and anally raped in his home by a friend, D, within a couple of hours of the alleged incident taking place. C suffered with chronic depression, anxiety, paranoid psychosis, and Obsessive Compulsive Disorder. He had attempted suicide several times and had been detained under the Mental Health Act on a number of occasions. C's psychiatrist described him as suffering from a persistent paranoia that he was being followed, that people 'were against him', and that someone was trying to attack him. In his Social Services records, C was described as 'prone to tell lies'.

In addition to his mental condition(s), $\mathrm{C}$ was an alcoholic. Both $\mathrm{C}$ and $\mathrm{D}$ had consumed large amounts of alcohol and several lines of cocaine on the evening of

\footnotetext{
119 See n.10 above.

120 In view of the SOR's limited remit, this is unsurprising. Tasked only with reforming substantive sexual offences, criminal evidence and procedure were not within the scope of the SOR's review.
} 
the alleged rape. C's accounts to investigators and medical professionals were inconsistent. They were also contradicted by independent evidence. For example, the report from the forensic medical examination stated that C's anal injuries were consistent with a more prolonged and vigorous episode of penetrative activity than that which $\mathrm{C}$ described. Further difficulties arose from the fact that $\mathrm{C}$ owed $\mathrm{D}$ a considerable amount of money. Finally, $\mathrm{C}$ had an extensive criminal history spanning 11 years, including a significant number of convictions for dishonesty offences. $^{121}$

All of this material would have to be disclosed to the defence under the Criminal Procedure and Investigations Act (CPIA) $1996^{122}$ as evidence tending to undermine the prosecution case and to assist the defence. Following disclosure, the prosecutor anticipated that the defence would claim that $\mathrm{C}$ was a fantasist and a liar: a line of defence that the prosecutor felt could not be adequately rebutted. Indeed, presenting $\mathrm{C}$ to the court as a witness of truth seemed to the prosecutor to be untenable. Despite her own belief that the complainant had indeed been raped, she concluded that C's evidence would be considered so unreliable that a judge would not allow the case to go to a jury. ${ }^{123}$

If it's a consent issue, the credibility of the witness - the victim-is the most important thing to me. It's the most important thing... His own psychiatrist said, 'Not a credible person.' Social Services report [which said C was prone to lying as a child]. But even his psychiatrist said it, and as an adult. And that's what it was all about. Now, I have to be sure that my victim, the complainant, is credible. If you've got someone who is a born liar, or someone who has dishonesty convictions, that person is not going to be credible. It's not to say that person has not been raped. That person is not going to be credible. He will go onto the witness stand and when cross-examined by the defence-as his own psychiatrist says- he will not be a good witness... I don't think we would have got past half-time because they would have put in cross-examination the mental issues; his lies; his dishonesty convictions. His credibility would have been damaged. [Prosecutor F]

Having assessed the evidential case as insufficient to provide a realistic prospect of conviction, the case could not proceed. ${ }^{124}$ The police were therefore advised to take no further action and D was released without charge. ${ }^{125}$

\footnotetext{
${ }^{121}$ Cf. $R$ (on the application of B) v Director of Public Prosecutions [2009] EWHC 106 (Admin). It is submitted that Case 8 may be distinguished on the basis of these additional factors pertaining to his reliability and credibility as a witness.

${ }^{122}$ As amended by the Criminal Justice Act 2003. See also the current Attorney General's Guidelines on Disclosure available online at http://www.cps.gov.uk/legal/section20/chapter_c.html\#02.

${ }^{123} R$ v Galbraith [1981] 1 WLR 1039; $R$ v Shippey [1988] Crim LR 767; $R$ v Brown [1998] Crim LR 196; $R$ v Shire [2001] EWCA Crim 2800.

124 The Code for Crown Prosecutors (2010, 4.3).

125 The police appealed against the CPS decision to discontinue in Case 8. Consequently, the evidential case was subjected not only to second review, but to third and fourth review by prosecutors of increasing seniority. That there was insufficient evidence to prosecute was confirmed on each occasion.
} 
The prosecutor's assessment that $\mathrm{C}$ was unreliable was not confined to the issue of consent; he was perceived as an unreliable witness per se. However, and in contrast to Case 17, independent evidence was available to the prosecution here. In addition to D's implicit admissions to sexual activity, scientific (DNA) evidence and medical (anal injuries) evidence showed that penetration had occurred. This independent evidence was not entirely consistent with C's account of nonconsensual penetration. On a rape charge, it may even have undermined rather than corroborated C's account. Had D been charged under section 30, however, the prosecution's evidential difficulties would have effectively evaporated. Penetration could be established without the need to call $\mathrm{C}$ as a witness. With his extensive history of mental disorder a jury may have been persuaded that $\mathrm{C}$ was unable to refuse and, owing to their longstanding friendship, any attempt by $\mathrm{D}$ to plead ignorance of C's condition would likely have been given short shrift. Indeed, faced with the evidence arrayed against him, and in the absence of a consent defence, D might well have pleaded guilty.

Yet, there was nothing in the case-file to suggest that alternative charges were even considered. Perhaps the prosecutor was unfamiliar with the section 30 offence, or was unaware that $\mathrm{C}$ potentially fell within its generous ambit. However, a further and less pessimistic explanation also springs to mind. Case 8 pre-dated the decision in $R$ v $C$. Thus, at the time the prosecutor was deciding how to proceed with this case, whether a complainant's mental disorder impeded choice was still considered to be issue-specific. The ability to refuse did not depend on the circumstances, or who was asking. Instead, $\mathrm{C}$ either had the capacity to consent to sexual relations, or he did not. As the complainant in Case 8 was a husband and father, a finding that he was unable to consent to sexual activity because of his mental disorder would have made a mockery of the rest of his life and family relationships. More troubling, and arguments regarding prosecutorial discretion notwithstanding, the police would presumably have had to turn their investigative attentions to C's wife.

\section{Summary and Conclusions}

This article began with the counter-intuitive suggestion that sexual offences perpetrated against mentally disordered persons appear to be brought to justice with greater frequency than other categories of sexual allegations. It was quickly demonstrated that, while we may be reassured that mentally disordered complainants' allegations of sexual victimisation are entering the system and are being brought to justice, we have little notion of how often this occurs. Indeed, calculated simplistically as 'crimes out' as a proportion of 'crimes in', conviction rates tend to present a distorted and misleading picture of the workings of the criminal justice process. Recognising our current inability to discover how often the protection of the criminal law is extended to mentally disordered complainants in sex cases, this article tentatively explored when, why, and how cases involving such complainants are (and are not) prosecuted.

We saw in relation to sexual offences involving child complainants that prosecutors appear to be unpersuaded of the merits of charging in the alternative. 
Instead, single charges are strategically selected which-as the prosecutor sees itbolster fact-finders' confidence in the strength of the prosecution case, and leave the prosecution room to manoeuvre should a defendant intimate his willingness to plead guilty. This strategy also appears to be adopted in sex cases involving mentally disordered complainants. So far as can be ascertained, the jury was presented with alternative charges in only one case in the law reports. Alternative charges under section 30 were entirely absent in the male rape sample cases analysed here. A more refined research question was therefore posed: if prosecutors prefer not to charge in the alternative, how do they decide which-if any-of a range of applicable offences to charge?

In exploring this question, the cases discussed in this article suggest that evidential factors appear to be more determinative of charge selection than a complainant's mental condition, or, indeed, their non-consent. In the absence of independent evidence, a case is unlikely to be prosecuted either as a non-consensual offence, or one perpetrated against a person with a mental disorder impeding choice. This is not a novel finding. Nor should it be considered particularly contentious: independent evidence correlates with prosecution and conviction in all crimes, not just sexual offences, and certainly not just sexual offences involving complainants with mental disorders. What is-or ought to be-contentious, however, are the probably unforeseen and perhaps unintended consequences of 'all or nothing' charging strategies.

Despite the SOR's efforts to strike an appropriate balance between protection and prohibition, the requirement that a complainant's mental disorder impedes choice is more readily satisfied in practice than was either envisaged or intended. Of the few reported cases to-date, only two involve complainants who can confidently be described as 'most severely disabled' and self-evidently incapable of consenting to sex. ${ }^{126}$ Yet, whether a complainant's mental disorder impedes choice is not a question of law but an issue for the fact-finder to determine. In the absence of a nonconsensual charge, and convinced that a defendant has done wrong, sympathetic fact-finders may be tempted to find that the complainant's mental disorder impeded choice. The average juror-or magistrate, for that matter-is neither a psychiatrist nor a lawyer, and is unlikely to consider that in convicting the defendant, the complainant's right to private life is implicated. Reluctant to set a conviction aside, the definitional element of the offence may subsequently be interpreted to fit the facts on appeal. These two factors-single charge indictments and purposive interpretations of the substantive law-are mutually reinforcing and lay the foundations for questionable case-building practices.

The core criticisms tentatively advanced here are exemplified by $R \vee C$, a case in which somebody, somewhere, decided that it would be more appropriateeasier?-to prove that the complainant could not consent to sexual activity than it would be to prove that she did not consent. In so doing, the defendants' (dubious) protestations of innocence appear to have furnished the prosecution with additional probative evidence on section 30 charges. In the absence of rape charges, the jury accepted that the complainant—an adult woman, married with children, isolated and

$\overline{126}$ Perera [2007] EWCA Crim 3277; Watts [2010] EWCA Crim 1824. 
cornered by two strangers plying her with drugs and demanding sex-was unable to consent because she was mad. This is fudged justice and, for those of us who believe that the law of sexual offences should attach the same priority to the right to say 'Yes' as it does to the right to say 'No', the broader trend it exemplifies is cause for concern. The first trickle of decided cases, taken together with the original empirical data presented in this article, suggests that our legislative endeavours to increase protection for one of society's most vulnerable groups is creating anomalies and raising the spectre of over-criminalisation, with direct implications for complainants' sexual autonomy.

Open Access This article is distributed under the terms of the Creative Commons Attribution Noncommercial License which permits any noncommercial use, distribution, and reproduction in any medium, provided the original author(s) and source are credited.

\section{References}

Ashworth, A., and M. Redmayne. 2010. The criminal process, 4th ed. Oxford: Oxford University Press. Brown, J., C. Hamilton, and D. O'Neill. 2007. Characteristics associated with rape attrition and the role played by scepticism or legal rationality by investigators and prosecutors. Psychology, Crime and Law 13: 355 .

Brownlee, I. 2004. The statutory charging scheme In England and Wales: Towards a unified prosecution system? Criminal Law Review: 896.

Burrows, J., M. Hopkins, R. Hubbard, A. Robinson, M. Speed, and N. Tilley. 2005. Understanding the attrition process in volume crime investigations. HORS 295. London: Home Office.

Burton, M, R. Evans, and A. Sanders. 2006. Implementing special measures for vulnerable and intimidated witnesses: The problem of identification. Criminal Law Review: 229.

Emerson, E., and C. Hatton. 2004. Estimating future need/demand for supports for adults with learning disabilities in England. Institute for Health Research: Lancaster University.

Feist, A., J. Ashe, J. Lawrence, D. McPhee, and R. Wilson. 2007. Investigating and detecting recorded offences of rape. Home Office Online Report 18/07. London: Home Office.

Gregory, J., and S. Lees. 1996. Attrition in rape and sexual assault cases. British Journal of Criminology 36: 1 .

Her Majesty's Crown Prosecution Service Inspectorate Her Majesty's Inspector of Constabulary. 2007. Without consent: A report on the joint review of the investigation and prosecution of rape offences. London: HMCPSI \& HMIC.

Herring, J. 2010. R v C: sex and mental disorder. Law Quarterly Review 126: 36.

Home Office. 1998. Speaking up for Justice: Report of the home office interdepartmental working group on the treatment of vulnerable or intimidated witnesses in the criminal justice system. London: Home Office.

Home Office. 2000a. Setting the boundaries: Reforming the law on sex offences. London: Home Office.

Home Office. 2000b. Achieving the best evidence in criminal proceedings: Guidance for vulnerable and intimidated witnesses including children. London: Home Office.

Home Office. 2002. Protecting the public: Strengthening protection against sex offenders and reforming the law on sexual offences. Cm. 5668. London: TSO.

Home Office. 2006. Sexual Offences Act 2003: A stocktake of the effectiveness of the act since its implementation. London: Home Office.

Home Office. 2007. Achieving best evidence in criminal proceedings: Guidance on interviewing victims and witnesses, and using special measures. London: Home Office.

Horvath, M., and L. Kelly. 2009. Multiple perpetrator rape: Naming an offence and initial research findings. Journal of Sexual Aggression 15: 83.

Keenan, C., and L. Maitland. 2000. Literature review of research into the law on sexual offences against children and vulnerable people' in Home Office, 2000a. Setting the boundaries: Reforming the law on sex offences (Volume 2), Appendix D2. London: Home Office. 
Kelly, L., J. Lovett, and L. Regan. 2005. A gap or a chasm? Attrition in reported rape cases. HORS 293. London: Home Office.

Lee, V., and C. Charles. 2008. Research into CPS decision-making in cases involving victims and key witnesses with mental health problems and/or learning disabilities. London: CPS.

Maher, G. 2010. Rape and other things: Sexual offences and people with mental disorder. Edinburgh Law Review 14: 129.

McCracken, K., A. Perry, and C. Phillips. 2009. Access to justice: A review of the existing evidence of the experiences of adults with mental health problems. Ministry of Justice Research Series 6/09. London: Ministry of Justice.

Phillips, C., D. Brown, Z. James, and P. Goodrich. 1998. Entry into the criminal justice system: A survey of police arrests and their outcomes. HORS 185. London: Home Office.

Sanders, A., R. Young, and M. Burton. 2010. Criminal justice, 4th ed. Oxford: Oxford University Press.

Stanko, B., and E. Williams. 2009. Reviewing rape and rape allegations in London: What are the vulnerabilities of the victims who report to the police? In Rape: Challenging contemporary thinking, ed. M. Horvath, and J. Brown. Devon: Willan Publishing.

Stern, V. 2010. The Stern review: A report by Baroness Vivien Stern CBE of an independent review into how rape complaints are handled by public authorities in England and Wales. London: Home Office.

Stevenson, K., A. Davies, and M. Gunn. 2004. Blackstone's guide to the sexual offences act 2003. Oxford: Oxford University Press.

Wolchover, D., and A. Heaton-Armstrong. 2008a. The rape myths myth. Counsel March 10.

Wolchover, D., and A. Heaton-Armstrong. 2008b. Rape myths and statistics. Counsel May 29.

Wolchover, D., and A. Heaton-Armstrong. 2008c. Debunking rape myths. New Law Journal 15: 117. 